\title{
The Effect of Thickness of Aluminium Films on Optical Reflectance
}

\author{
Robert Lugolole and Sam Kinyera Obwoya \\ Department of Physics, Kyambogo University, P.O. Box 1, Kyambogo, Kampala, Uganda \\ Correspondence should be addressed to Sam Kinyera Obwoya; ksobwoya@yahoo.co.uk
}

Received 25 December 2014; Revised 29 January 2015; Accepted 30 January 2015

Academic Editor: Yuan-hua Lin

Copyright (C) 2015 R. Lugolole and S. K. Obwoya. This is an open access article distributed under the Creative Commons Attribution License, which permits unrestricted use, distribution, and reproduction in any medium, provided the original work is properly cited.

\begin{abstract}
In Uganda and Africa at large, up to $90 \%$ of the total energy used for food preparation and water pasteurization is from fossil fuels particularly firewood and kerosene which pollute the environment, yet there is abundant solar energy throughout the year, which could also be used. Uganda is abundantly rich in clay minerals such as ball clay, kaolin, feldspar, and quartz from which ceramic substrates were developed. Aluminium films of different thicknesses were deposited on different substrates in the diffusion pump microprocessor vacuum coater (Edwards AUTO 306). The optical reflectance of the aluminium films was obtained using a spectrophotometer (SolidSpec-3700/DUV-UV-VIS-NIR) at various wave lengths. The analysis of the results of the study revealed that the optical reflectance of the aluminium films was above $50 \%$ and increased with increasing film thickness and wavelength. Thus, this method can be used to produce reflector systems in the technology of solar cooking and other appliances which use solar energy.
\end{abstract}

\section{Introduction}

The need for reflectance of light energy and heat energy is continually increasing due to the global rapid growing population, industrial development, and domestic needs. The reflectance of solar energy can reduce use of nonrenewable energy sources such as fossil fuels, petroleum fuels, and fissionable minerals. According to Intergovernmental Panel on Climate Change Plenary xxxvii [1], such energy sources lead to the emission of greenhouse gases like water vapour, carbon dioxide, methane, nitrous oxide, ozone, particulate matter, nitrogen oxide, sulphur dioxide, and arsenic and fluorinated compounds, which have increased in the atmosphere since the start of the industrial era in 1750 leading to atmospheric air pollution. Due to prolonged emission of greenhouse gases, greenhouse effect has brought about thinning of the ozone layer in the stratosphere. The global average temperature has increased by $0.6^{\circ} \mathrm{C}$ since the mid-20th century due to anthropogenic activity [2-4]. Reflectance of solar energy is used in solar thermal devices such as solar cookers, for cooking, water heating, space heating, space cooling, and heat generation process. Solar cookers are easy to build, are smoke free, nonpollutant [5] and can conserve the environment by using heat-reflecting mirrors [6]. The mean daily illumination intensity of the sun in the equatorial zone is in the range of $5-7 \mathrm{kWh} / \mathrm{m}^{2}$ and has more than 275 sunny days in the year. This can make solar cooker use possible in Uganda because it is in the equatorial zone. The use of solar cookers will save women and children walking long distances looking for wood and significantly reduce the amount of time women spent tending open fires each day for other developmental works [7]. Wood and charcoal supply over $90 \%$ of Uganda's cooking energy requirements; thus, the use of solar cookers will also reduce deforestation, which currently is at an alarming rate. This paper therefore investigated the effectiveness of solar cookers made by depositing thin aluminium films on ceramic substrates for domestic purposes.

\section{Experimental Procedures}

2.1. Material Processing. Aluminium films were deposited on to ceramic substrates that were developed from predetermined minerals from Uganda. The minerals that were used include ball clay, kaolin, quartz, and feldspar. Ball clay was obtained from Ntawo deposit in Mukono district. The site 
has clay of finite particle sizes that form readily mouldable sticky mass when mixed with water [8]. It becomes hard and brittle, retains its shape when heated [9], and is no longer susceptible to the action of water. Kaolin and feldspar were collected from Mutaka deposit in Bushenyi district because it has high content of alumina while quartz was collected from Dimu deposit in Masaka district because the site has relatively pure fine quartz particle sizes [10]. The mineral particle sizes of $32 \mu \mathrm{m}$ for ball clay, $45 \mu \mathrm{m}$ for kaolin, $53 \mu \mathrm{m}$ for feldspar, and finally $32 \mu \mathrm{m}$ for quartz were chosen to minimise porosity and increase densification of the samples prepared. This is because small particle sizes increase particle content per unit volume which decreases the average interparticle distance of the clay matrix resulting in close packing of particles of the ceramic [11]. In the study, the thicknesses of aluminium films that were deposited on the ceramic substrates and the wave lengths of the radiation were the independent variables, while the dependent quantity was the optical reflectance of the aluminium films.

The ball clay slip was sieved mechanically and carefully through $80 \mu \mathrm{m}, 53 \mu \mathrm{m}$, and $32 \mu \mathrm{m}$ sieves in order to get the required fine clay mineral size that could form smooth hard ceramic bodies. The slurry finally obtained after sieving was poured on the plaster of Paris mould where excess water was removed, thus, forming a semidry cast. The semidry cast was again left to continue drying in air at room temperature for seven days [12] to get rid of some of the remaining water in the cast. A drying oven was later used to completely dry the clay samples at a temperature of $105^{\circ} \mathrm{C}$ for five hours in order to be certain of driving away all the water in the pores of the clay mass. The required dry body was removed from the oven after cooling. It was crushed and then ground in a ball mill to obtain fine powders, by Kingery et al. [13], which were pressed into rectangular samples and then fired to yield mechanically strong ceramic bases.

Kaolin, feldspar, and quartz were dry milled for three days in a ball mill to reduce their particle sizes to ease sieving. The fine powder of kaolin was sieved mechanically through standard sieves of particle sizes $150 \mu \mathrm{m}, 80 \mu \mathrm{m}$, and $45 \mu \mathrm{m}$, while that of feldspar was similarly sieved through $150 \mu \mathrm{m}$, $80 \mu \mathrm{m}$, and $53 \mu \mathrm{m}$ sieve meshes, and finally that for quartz was sieved through the $150 \mu \mathrm{m}, 80 \mu \mathrm{m}, 53 \mu \mathrm{m}$, and $32 \mu \mathrm{m}$ sieve meshes.

The $32 \mu \mathrm{m}, 45 \mu \mathrm{m}, 53 \mu \mathrm{m}$, and $32 \mu \mathrm{m}$ of the fine powders were weighed separately in the proportions of $30 \%$ ball clay, 25\% kaolin, 30\% feldspar, and 15\% quartz, respectively, and then mixed thoroughly to form a blended mixture. Each ceramic substrate was made from a mass of $2.03 \times 10^{-2} \mathrm{~kg}$ drawn from the mixture formed. In addition to the ball clay, bentonite organic binder amounting to $3 \%$ of $2.03 \times 10^{-2} \mathrm{~kg}$ mass was added to each sample as an auxiliary material to form a colloidal mixture, in order to increase bonding of the particles. Each colloidal mixture was thoroughly mixed using a clean automated mortar for fifteen minutes to obtain uniform particle distribution, which greatly improves the forming process of ceramic materials [13]. The colloidal samples were dried under the sun for seven days and then crushed into finer powder using a roller on a clean flat metallic surface. Each sample, as shown in Figure 2, was slowly compacted in

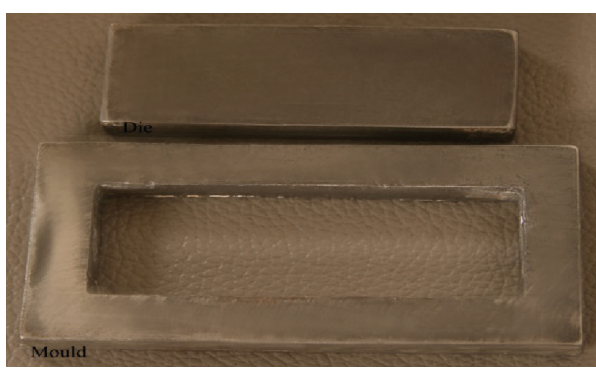

FIgURE 1: Compaction mould and die.

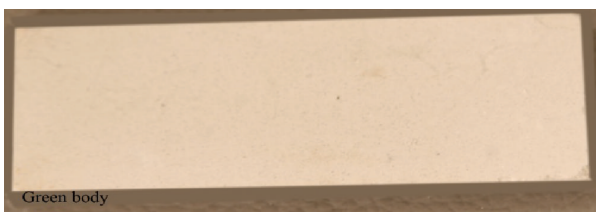

FIGURE 2: Green body.

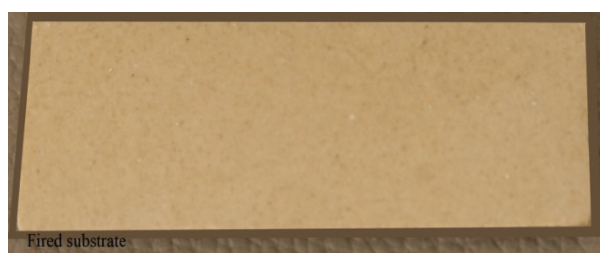

Figure 3: Ceramic substrate after firing.

a die mould as shown in Figure 1, at a pressure of $152 \mathrm{MPa}$ by use of a hydraulic press (PW-40). A total of twenty four rectangular slides of length $7.70 \times 10^{-2} \mathrm{~m}$, width $2.87 \times 10^{-2} \mathrm{~m}$, and thickness $5.34 \times 10^{-3} \mathrm{~m}$ were made. The green slides were carefully removed from the mould and air-dried for four days to drive out some remaining water and to become hard before firing.

The dry samples were fired in an electrical furnace at a rate of $6^{\circ} \mathrm{C}$ per minute under controlled temperatures and varying pressures. The furnace temperature was held in stages, at a temperature of $110^{\circ} \mathrm{C}$ for two hours to drive out the ordinary water and at $450^{\circ} \mathrm{C}$ to get rid of the hydroxyl ions. According to Ryan [14], some crystalline changes take place at the $\alpha$ $\beta$ quartz inversion due to quartz expansion, so the rate of temperature rise was slow near the inversion temperature of $573^{\circ} \mathrm{C}$ to avoid cracking of the body. The temperature was then raised to $1250^{\circ} \mathrm{C}$ and then held there for two hours for the body to mature. Finally, the samples were air-cooled in the furnace and then removed carefully in order to avoid scratches before aluminium was deposited on them as shown in Figure 3. The slides which got out of the kiln were of length $6.92 \times 10^{-2} \mathrm{~m}$, width $2.54 \times 10^{-2} \mathrm{~m}$, thickness $4.19 \times 10^{-3} \mathrm{~m}$, and mass $1.627 \times 10^{-2} \mathrm{~kg}$.

Aluminium was used to form the thin film reflecting surfaces on ceramic substrates to concentrate light and heat because it is ductile, has a low density of $2.70 \times 10^{3} \mathrm{kgm}^{-3}$ with an acoustic impedance of $8.17 \times 10^{6} \mathrm{kgm}^{-2} \mathrm{~s}^{-1}$, and is resistant to oxidation. Similarly, aluminium was used because 
it is widely available primarily as ore bauxite that makes $8 \%$ of the earth's solid surface [15]. It is cheap and nonmagnetic, does not easily ignite, is silvery white, and has a melting point of $660.4^{\circ} \mathrm{C}$ and evaporation temperature of $1390^{\circ} \mathrm{C}$ which make it a good reflector of both visible light and heat. Aluminium films used as metallization contacts have low specific resistivity, good thermal stability, high uniformity across the flat substrate, low particle contamination, and good adherence to substrate. These properties have led aluminium to be irreplaceable and its demand is on increase in many areas of today's rapidly developing technology especially optical industries [16]. Highly specular aluminium films made in an ultrahigh vacuum deposition process have a solar reflectance of $92 \%$. The problem is that the optical reflectance of aluminium deteriorates upon exposure to the outdoor environment at a time scale of less than one year. Aluminium foil which is currently used as the reflecting surface on solar cookers is quite easy to damage and is also known to darken when exposed to moisture. This creates wear of aluminium foil leading to the formation of small pinholes in it when it comes in contact with different metals or food that is highly salted or acidic [17].

Vulnerable aluminium surface must, therefore, be protected by some kind of nonabsorbing coating from degradation. Several techniques have been applied; anodic oxidation coating [18], lacquering with $\mathrm{PVF}_{2}, \mathrm{PVF}$, and PMMA [19, 20], vacuum deposited thin dielectric films [21], and sol-gel deposition of thin dielectric films. Aluminium surface can also be protected by vacuum deposition of the metal onto PMMA [22, 23] whereas, to obtain its long-term stability, a second surface mirror is deposited and thereafter sealed. Other surface treatments that can be designed in order to improve the surface properties of aluminium films such as wear resistance, corrosion resistance, and reflectivity are such as electrochemical brightening, electropolishing, annealing, and glazing [24]. Silicon dioxide overcoating protects aluminium and enables careful cleaning to take place [25]. This is fortunate because most materials, including aluminum, have better adherence if they are evaporated onto heated substrates [26].

2.2. Deposition of Aluminium Films. Aluminium adheres well to both silicon and silicon dioxide and can be easily vacuum deposited since it has a low boiling point and has high conductivity [27]. Aluminium films of specific different thicknesses were deposited on different ceramic slide substrates in the diffusion pump microprocessor vacuum coater (Edwards AUTO 306) as shown in Figure 4. The power was regulated at a value of $1.30 \mathrm{~kW}$ to heat, melt, and vaporize aluminium at a temperature of $660^{\circ} \mathrm{C}$. The aluminium film thicknesses, $T$, deposited on the slides A, B, C, D, E, and F are shown in Table 1.

2.3. Measurement of Optical Reflectance. The optical reflectance of specific thicknesses, $T$, of aluminium films deposited on the ceramic slides was measured and recorded over a range of wavelength, $\lambda, 500 \mathrm{~nm}$ to $2500 \mathrm{~nm}$ using a SolidSpec3700/DUV-UV-VIS-NIR. Four samples were considered to

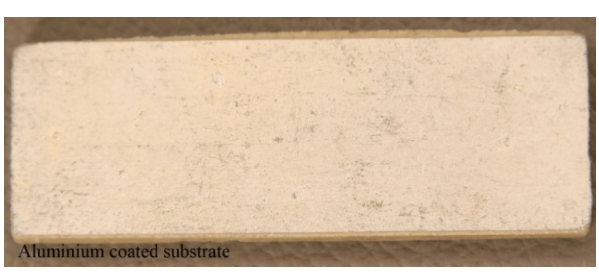

FIGURE 4: Aluminium coated ceramic substrate.

TABLE 1: Thicknesses of aluminium films deposited on the slides.

\begin{tabular}{ccccccc}
\hline Slides & A & B & C & D & E & F \\
\hline$T / n m$ & 12.3 & 100 & 136 & 396 & 480 & 750 \\
\hline
\end{tabular}

obtain the average optical reflectance as shown in Table 2. The data in Table 2 was inserted into Matlab software to generate graphs of optical reflectance against wave length as shown in Figure 5.

\section{Experimental Results}

3.1. Optical Reflectance of Aluminium Films. The percentage of optical reflectance of aluminium films deposited on ceramic substrates at various wave lengths is shown in Table 2 .

\section{Discussion and Conclusions of Results}

\subsection{Discussion of Results}

4.1.1. Aluminium Films on Ceramic Bases. The various thicknesses of aluminium films deposited on the ceramic bases were $12.3 \mathrm{~nm}, 100 \mathrm{~nm}, 136 \mathrm{~nm}, 396 \mathrm{~nm}, 480 \mathrm{~nm}$, and finally $750 \mathrm{~nm}$. This range was chosen because when the films deposited were less than $5 \mathrm{~nm}$, the reflectance was mainly due to the base after absorbing more of the energy. When the films built were above $1 \mu \mathrm{m}$, their adhesion to the ceramic substrate could no longer balance the stress when deposited by evaporation. Such films led to the clouding effect which limited their use in the infrared range. The deposition of films on the substrates was at a pressure of $9 \times 10^{-7} \mathrm{MB}$ because aluminium films strongly adhere on the substrates when deposition is carried out at a pressure less than $10^{-7}$ of atmospheric pressure, to avoid oxidation, and is used to prepare thin films with controlled chemical composition [28]. The vacuum deposition process was selected for the deposition of thin films over other processes such as electrochemical deposition and flame spraying. This is because it gave balanced homogeneous films onto the ceramic bases particularly determined by the smoothness and cleaning level of the substrates, the deposition temperature of $660^{\circ} \mathrm{C}$, and the chamber pressure of $6 \times 10^{-7} \mathrm{MB}$. This prevented aluminium from being removed by acids or alkali solutions because it was chemically inert due to the aluminium modulus of elasticity of $7.1 \times 10^{10} \mathrm{~Pa}$, kaolin, which has alumina that was useful in reinforcing the films, and aluminium would balance the mechanical stress which is the principal 
TABLE 2: Optical reflectance of aluminium films deposited on ceramic surfaces.

\begin{tabular}{lcccccccccccc}
\hline$\lambda / \mathrm{nm}$ & 500 & 700 & 900 & 1100 & 1300 & 1500 & 1700 & 1900 & 2100 & 2300 & 2500 \\
\hline T/nm & & \multicolumn{7}{c}{ Percentage of optical reflectance of aluminium films } \\
\hline A & 21.435 & 26.895 & 26.416 & 26.139 & 27.961 & 28.890 & 29.866 & 31.191 & 32.421 & 33.560 & 34.341 \\
B & 53.707 & 61.015 & 63.591 & 67.753 & 70.279 & 71.767 & 74.008 & 73.628 & 75.914 & 75.934 & 77.342 \\
C & 69.174 & 71.416 & 70.952 & 73.876 & 75.257 & 75.984 & 76.442 & 76.896 & 78.898 & 78.617 & 79.799 \\
D & 76.330 & 76.215 & 72.713 & 78.480 & 78.008 & 80.082 & 79.009 & 79.631 & 81.514 & 81.699 & 82.657 \\
E & 81.634 & 79.898 & 76.222 & 79.444 & 80.294 & 80.664 & 81.071 & 81.297 & 83.137 & 82.717 & 83.807 \\
F & 93.074 & 91.827 & 93.410 & 93.950 & 94.221 & 94.321 & 94.687 & 95.505 & 95.253 & 95.851 & 95.953 \\
\hline
\end{tabular}

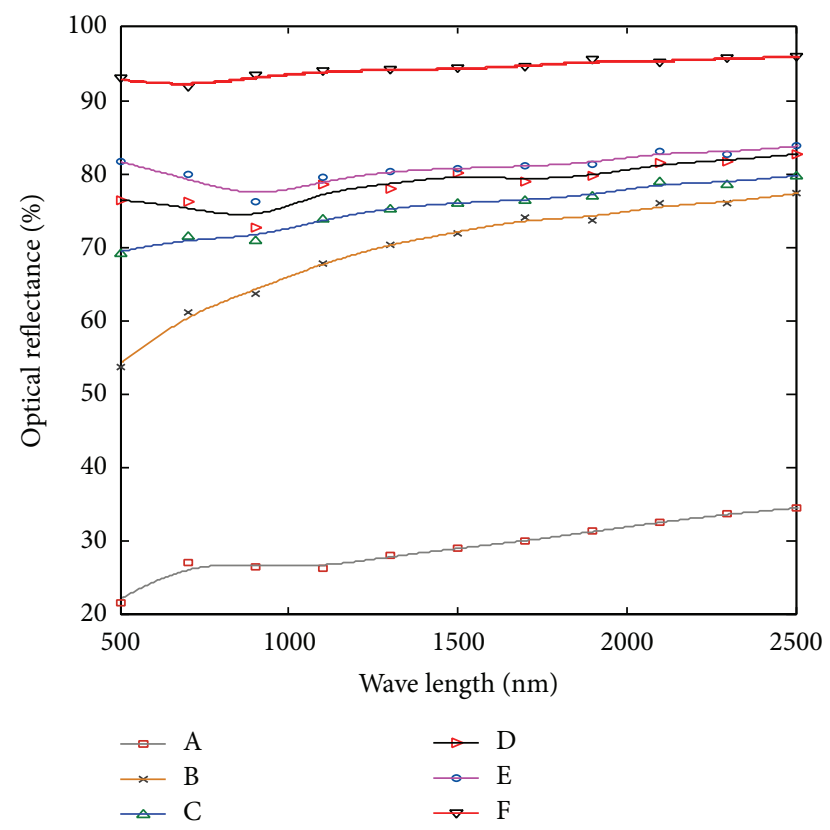

FIGURE 5: Optical reflectance of samples A, B, C, D, E, and F.

factor for limiting the thickness of films when deposited by evaporation on substrates. It is the reason why aluminium films deposited on the fabricated ceramic bases had no effect even after five months of study. It is also because physical vapour deposition produces reflective enhancing oxide layers which avoid further oxidation and corrosion.

4.1.2. Optical Reflectance. In this particular study, over $50 \%$ of the incident radiation falling onto the films deposited on the ceramics was reflected as compared to the total light absorbed and transmitted except for sample A. This so far is much better than aluminium foil which on its own reflects about $55 \%$ of visible light that even lowers to about 35\% when creased and exposed to harsh atmospheric conditions [29]. The graphs of optical reflectance against wave length are shown in Figure 5. The best fit used for the graphs at a 95\% level of confidence from a smoothing parameter was a smoothing spline function $f(x)$ in contrast to Gaussian, interpolant, power, linear functions and so forth. The polynomial $f(x)$ for each graph had a high $R$-square value between 0.9000 and 1.0000 to give a working standard square error (SSE) and root mean square error (RMSE) which produced smooth curves with goodness of fit due to reduced kinks. Some kinks arose because of change of the spectrophotometer detectors especially when the photomultiplier changed to indium gallium arsenide between $700 \mathrm{~nm}$ and $1000 \mathrm{~nm}$ and to lead selenide between $1500 \mathrm{~nm}$ and $1800 \mathrm{~nm}$, respectively.

The reflectance of aluminium generally increased with increase in thickness of the aluminium films and with increase in the radiation wave length as per Figure 5. This is because aluminium exhibits free electron behaviour at various solar wavelengths over the entire solar wavelength interval [30], due to its small interband transitions. At a $95 \%$ level of confidence, the standard deviation obtained for the experimental study on samples A to F was lowest at 1.009 for sample D at a wave length of $2100 \mathrm{~nm}$ and highest at 8.885 for sample A at a wave length of $2100 \mathrm{~nm}$ which shows the consistency of the results of all samples.

The reflectance of sample $A$ at all wave lengths was the lowest below $35 \%$ because much of the light was transmitted by the film and absorbed by the base. The low reflectance of A was also attributed to the nonlinearity and nonsmoothness of the surface. Between $700 \mathrm{~nm}$ and $900 \mathrm{~nm}$, the reflectance of all the samples decreased slightly apart from A and B. This is because aluminium maintains high reflectance over the entire solar wavelength interval with the smallest value around $0.82 \mu \mathrm{m}[31,32]$. The inconsistency in the reflectance for all samples below $600 \mathrm{~nm}$ wave length was because of the absence of the nitrogen pumping accessory which was not integrated in the spectrophotometer used during the study. Reflectance became stable between $1000 \mathrm{~nm}$ and $2500 \mathrm{~nm}$ for all samples due to increasing wavelength of the radiation into the infrared band. Maximum steady reflectance of above $90 \%$ was achieved by sample $\mathrm{F}$ which showed a markedly higher jump in reflectance than other samples for all wave lengths between $800 \mathrm{~nm}$ and $2500 \mathrm{~nm}$ due to minimal absorption of the radiation by the base because it had $750 \mathrm{~nm}$ aluminium film thickness. It is also an attribute of the radiation of high wave length being less penetrative than for the short wave length band. The $750 \mathrm{~nm}$ aluminium film thickness offers a smooth surface with reduced transmission and absorption of light by the aluminium film and its base. Any radiation lost in sample $\mathrm{F}$ was due to tolerable multiple internal reflections and absorption of light and heat by the film itself and the impurities therein contained such as iron, nickel, chromium, and manganese rather than the support base. 


\section{Conclusions}

The results of the study showed that aluminium films deposited on the ceramic bases in a vacuum coater have high optical reflectance. However, the various thicknesses of aluminium films directly affected the optical reflectance at different wavelengths. Thus, from the overall experimental analysis carried out, salient conclusions arising from this work are summarized as follows.

(1) The optical reflectance of aluminium increased with increase in film thickness.

(2) The optical reflectance of aluminium increased with increase in the radiation wavelength.

(3) Suitable solar cookers and other appliances using solar energy can be developed by vacuum deposition of aluminium films on the ceramic bases fabricated from ball clay, kaolin, quartz, and feldspar. This may alleviate the problem of lack of fuel for food preparation, pollution by fossil fuels, and emission of greenhouse gasses leading to global warming.

\section{Conflict of Interests}

The authors declare that there is no conflict of interests regarding the publication of this paper.

\section{Acknowledgments}

The authors would like to thank the staff at Kyambogo University for their guidance and support during the course of the study and research. Further thanks and gratitude go to Makerere and Nairobi University Physics Departments, the Physics Department and IPPS, Uppsala University, Sweden, Uganda Industrial Research Institute, Ministry of Energy, Uganda, Uganda National Bureau of Standards, and Uganda Analytical Department for the provision of quality of equipment, resources, and laboratories for this study. They are grateful to their course mates, relatives, and friends particularly Shema Blessing for their support.

\section{References}

[1] Intergovernmental Panel on Climate Change Plenary, Assessment of Intergovernmental Panel on Climate Change, 2007, http://www.energyquest.ca.gov.

[2] M. Kandlikar, C. C. O. Reynolds, and A. P. Grieshop, "A perspective paper on black carbon mitigation as a response to climate change," Copenhagen Consensus Center Report, 2010.

[3] J. Greene, Harnessing the Sun to Benefit People and the Environment, vol. 1, no. 1, Solar Cookers International, 2014.

[4] A. R. Shashikala, A. K. Sharma, and D. R. Bhandari, "Solar selective black nickel-cobalt coatings on aluminum alloys," Solar Energy Materials and Solar Cells, vol. 91, no. 7, pp. 629635, 2007.

[5] J. Li, D. R. Alexander, H. Zhang et al., "Propagation of ultrashort laser pulses through water," Optics Express, vol. 15, no. 4, pp. 1939-1945, 2007.
[6] E. Valkonen and B. Karlsson, "Optimization of metal-based multilayers for transparent heat mirrors," International Journal of Energy Research, vol. 11, no. 3, pp. 397-403, 1987.

[7] Solar lifeline saves Darfur women, CNN. 17-09-2007, 2015.

[8] O. K. Sam, Effects of microstructure on mechanical properties of selected clays from Uganda [Ph.D. thesis], Makerere University, Kampala, Uganda, 2004.

[9] A. M. V. Agbayani and A. A. Espinosa, Ceramic Tiles from Crassostrea iredalei, Philippine Normal University, Boca Raton, Fla, USA, 2006.

[10] P. O. Wilberforce, Characterisation of ceramic raw minerals in Uganda for production of electrical porcelain insulators [Doctoral Thesis in Material Science], KTH, Stockholm, Sweden, 2010.

[11] S. Zhang, X. Y. Cao, Y. M. Ma, Y. C. Ke, J. K. Zhang, and F. S. Wang, "The effects of particle size and content on the thermal conductivity and mechanical properties of $\mathrm{Al}_{2} \mathrm{O}_{3}$ /high density polyethylene (HDPE) composites," Express Polymer Letters, vol. 5, no. 7, pp. 581-590, 2011.

[12] A. J. Moulson and J. M. Herbert, Electro Ceramics Materials Properties Applications, Chapman \& Hall, London, UK, 1990.

[13] W. D. Kingery, H. K. Bowen, and D. R. Uhlmann, Introduction to Ceramics, Wiley-Interscience, New York, NY, USA, 2nd edition, 1976.

[14] W. Ryan, Properties of Ceramic Raw Materials, Pergamon Press, Oxford, UK, 1978.

[15] U.S. Geological Survey, Mineral Commodity Summaries, U.S. Geological Survey, 2014.

[16] Z. Fekkai, N. Mustapha, and A. Hennache, "Optical, morphological and electrical properties of silver and aluminium metallization contacts for solar cells," American Journal of Modern Physics, vol. 3, no. 2, pp. 45-50, 2014.

[17] J. Harrison, Investigation of Reflective Materials for the Solar Cooker, Florida Solar Energy Center, 2001.

[18] British Standards Institution, Methods of Test for Anodic Oxidation Coatings on Aluminium and Its Alloys, British Standards Institution, 2013.

[19] R. B. Pettit and J. M. Freese, "Wavelength dependent scattering caused by dust accumulation on solar mirrors," Solar Energy Materials, vol. 3, no. 1-2, pp. 1-20, 1980.

[20] P. Nostell, A. Roos, and B. Karlsson, "Ageing of solar booster reflector materials," Solar Energy Materials and Solar Cells, vol. 54, no. 1-4, pp. 235-246, 1998.

[21] Acmite Market Intelligence, Market Report: Global Optical Coatings Market, Acmite Market Intelligence, 2014.

[22] P. Schissel, G. Jorgensen, C. Kennedy, and R. Goggin, "SilveredPMMA reflectors," Solar Energy Materials and Solar Cells, vol. 33, no. 2, pp. 183-197, 1994.

[23] P. Schissel, G. Jorgensen, and R. Pitts, "Application experience and field performance of silvered polymer reflectors," in Proceedings of the Solar World Congress, vol. 2, pp. 2076-2081, Pergamon Press, Denver, Colo, USA, 1991.

[24] B. Perers, B. Karlsson, and M. Bergkvist, "Intensity distribution in the collector plane from structured booster reflectors with rolling grooves and corrugations," Solar Energy, vol. 53, no. 2, pp. 215-226, 1994.

[25] Starna Optical Coatings, http://www.optiglass.com/ukhome/d_ ref/xrefsets.html.

[26] "Radiative heat transfer," Journal of the Optical Society of America, vol. 51, no. 7, 1961. 
[27] Z. H. Levine and B. Ravel, "Identification of materials in integrated circuit interconnects using x-ray absorption nearedge spectroscopy," Journal of Applied Physics, vol. 85, no. 1, pp. 558-564, 1999.

[28] P. Wißmann and H.-U. Finzel, Electrical Resistivity of Thin Metal Films, vol. 223 of Springer Tracts in Modern Physics, Springer, Berlin, Germany, 2007.

[29] The European Engineering Properity Database for Wrought Aluminium and Aluminium Alloys, 1992, 2 diskettes.EAA, KTH.

[30] Aluminum Federation, The Properties of Aluminum and Its Alloys, Aluminum Federation, Birmingham, UK, 1993.

[31] W. B. Frank, Ullmann's Encyclopedia of Aluminum Industrial Chemistry, Wiley-VCH, 2009.

[32] American Society for Metals, Aluminium-Properties and Physical Metallurgy, American Society for Metals, Metals Park, Ohio, USA, 1984. 

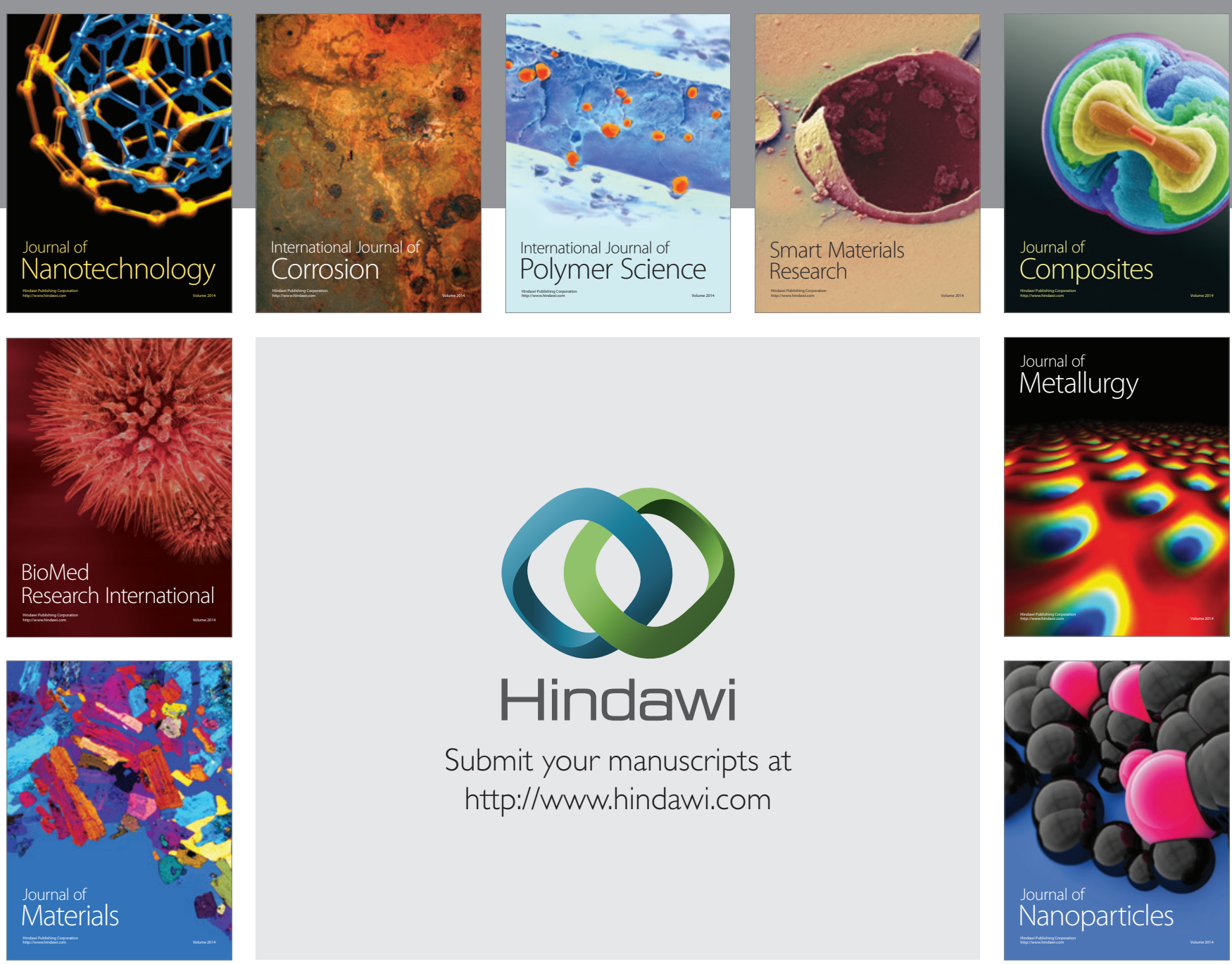

Submit your manuscripts at http://www.hindawi.com
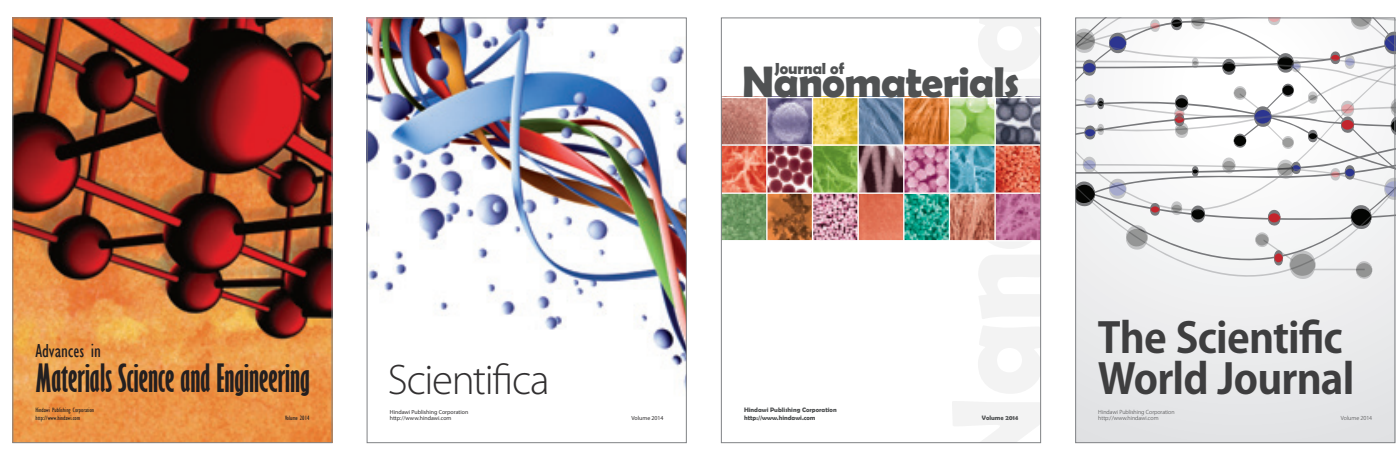

\section{The Scientific World Journal}
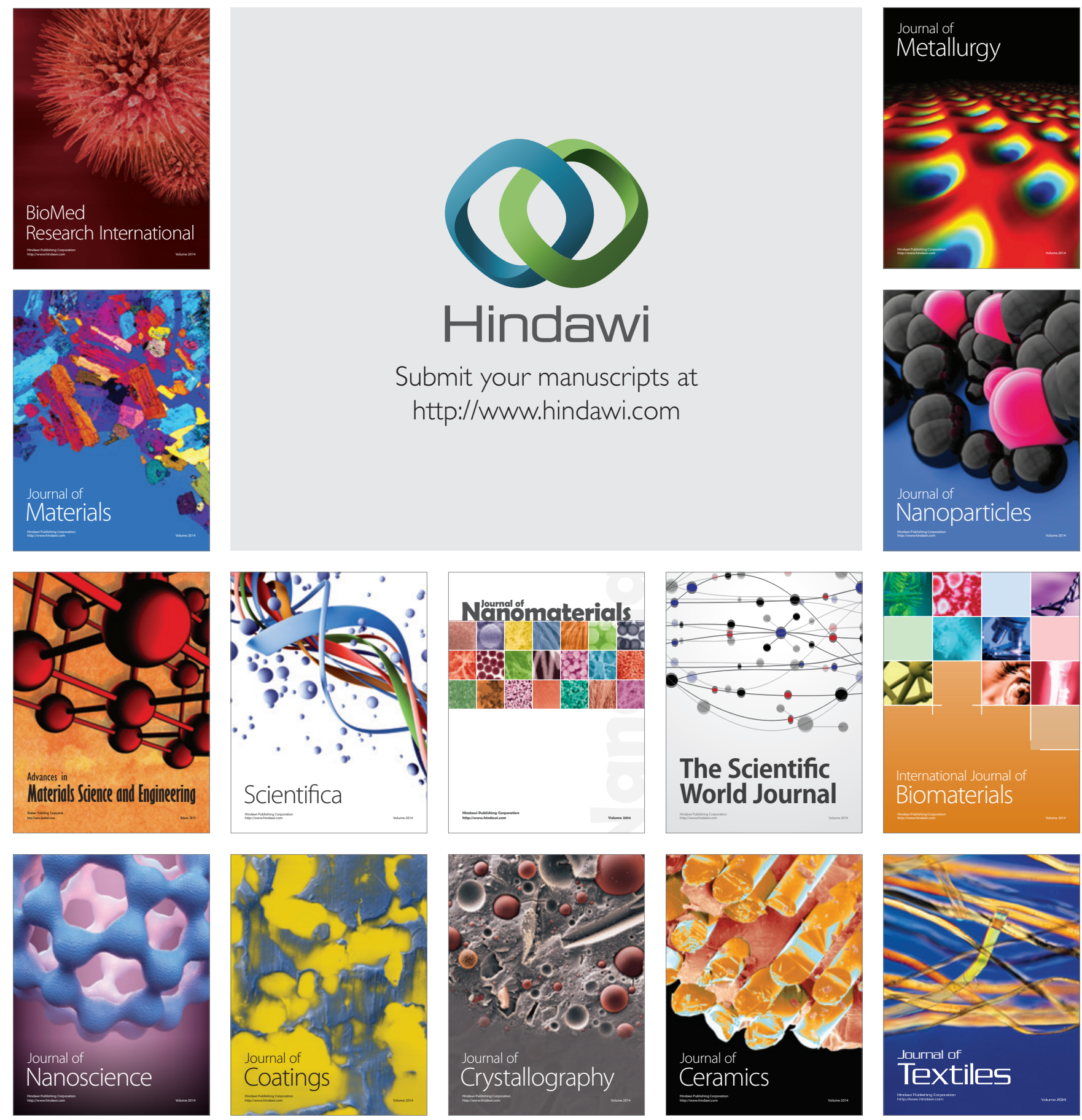